\title{
Kaolin Stabilization of Olokoro Lateritic Soil Using Bone Ash as Admixture
}

\author{
Onyelowe, K. C \\ Department of Civil Engineering, College of Engineering, \\ Michael Okpara University of Agriculture, Umudike. P.M.B.7267, \\ Umuahia 440109, Abia State. \\ konyelowe@mouau.edu.ng,kconyelowe@yahoo.com
}

\begin{abstract}
This study focused on the stabilizing potential of kaolin using bone ash as an admixture on the stabilization of Olokoro lateritic soil. Kaoline which is a deposite by the river bank was sourced from Agbaghara in Imo State, Nigeria and the bones from an abattoir in afo-ogbe, Mbaise also in Imo State. The Kaoline was grinded into powder and the bones burnt in open air using animal fat as fuel. The residue was fed into furnace at about $1000^{\circ} \mathrm{C}$, allowed to cool, milled and sieved with sieve of aperture $75 \mu \mathrm{m}$ to obtain bone ash before use. The following engineering confirmatory tests were carried out on the samples: Chemical Composition of Bone Ash, Sieve Analysis, Attergberg Limit, Compaction Test, California Bearing Ratio (CBR), Specific Gravity and Undrained Triaxial Test. The kaolin was at a fixed proportion of $10 \%$ while the bone ash was added in the proportions of 2\%, 4\%, 6\%, 8\% and 10\% for Attergberg Limit Test, Compaction Test, California Bearing Ratio (CBR) Test and Undrained Triaxial Test. The chemical composition test provided the chemical elements existing in the samples and shows that for bone ash it contains more calcium than can be accounted for on the basis of carbonate and phosphate. The soil sample was classified according to AASHTO soil classification system from the results obtained from Sieve Analysis and Alterberg Tests as A-7-5. The soil type is clayey soil with Plastic Limit of 26.9 and Liquid Limit of 60.0 and Plasticity Index of 33.1. Which is not good for construction purposes, hence the need for stabilization arises. From the compaction test carried out it was found that the addition of bone ash to the soil at different percentages reduced the optimum moisture $(O M C)$ content and increased the maximum dry density $(M D D)$. The CBR result showed that at $10 \%$ Kaolin content, addition of bone ash up to $8 \%$ increased the CBR and further increase to $10 \%$ Bone Ash decreased CBR. It improved from $29.7 \%$ at $0 \%$ of both Kaolin and Bone Ash to $80.3 \%$ at $8 \%$ Bone Ash and $10 \%$ Kaolin. This value is acceptable for base course materials according to general specifications for road, foundation and bridges by Federal Ministry of Works, Lands and Transport. The Specific Gravity Test showed 2.63 which fell within given value for clay minerals. The Triaxial test shows that at the $8 \%$ BA and 10\% Kaolin the cohesion improved
\end{abstract}

Keywords: Kaolin stabilization, Olokoro lateritic soil, bone ash, admixture, Onyelowe

\section{INTRODUCTION}

Presently, the use of engineering soil in construction works or foundation purposes has been a source of worry because the soils don't meet geotechnical engineering requirements hence the need for stabilization or improvement of same to achieve the desired results (Agininuola and Agbede, 2009; Behzad and Huat, 2008; Salahudeen and Akiije, 2014 ). Researchers today are developing and looking into efficient means of utilizing both agricultural and environmental waste products to combat soil instability problems. One type of agricultural waste that is of great concern in both urban and rural area of Nigeria is abattoir or slaughter-house waste. Abattoir wastes often contain blood, bones, horns, fat organic and inorganic solids and salts and chemical added during processing operation. The bones partially burnt are seen around most slaughters houses in market areas in major towns in Nigeria. Alternative means of disposing this waste is sourced in this study that would be environmental friendly as well as contributing to income of people. Bone is a dynamic tissue that performs mechanical, biological and chemical function. The main component of born is hydroxyapatite, as well as amorphous forms of calcium phosphate possibly including carbonate. Bone chemical and physical properties are affected by age, nutrition, hormonal status and disease. Borne Ash (BA) is a whitish powdery residue left from the burning (calcinations) of bones. The ash is composed majorly of $\mathrm{P}_{2} \mathrm{O}_{3}$ and $\mathrm{CaO}_{2}$ in the form of calcium phosphate $\mathrm{Ca}_{3}\left(\mathrm{PO}_{4}\right)_{2}$ or modified hydroxyapatite $\left(\mathrm{Ca}_{5}\left(\mathrm{PO}_{4}\right)_{3} \mathrm{OH}\right)$ (Agininuola and Agbede, 2009). The main chemical compositions of natural bone are expressed in 
terms of calcium Oxide and phosphorus pent oxide and at $32.1 \%, 28.8 \%$ respectively. Bone ash is obtained from calcination of bone at approximately $1100^{\circ} \mathrm{C}$ and then cooling, milling and sieving through the 325 mesh sieve. Bone Ash can also be made from bovine bones by burning the bones at $100^{\circ} \mathrm{C}$ for about 6 to 12 hours and then placed in a muffler furnace heated up to $1000^{\circ} \mathrm{C}$. The left over or residue is a mineral shell of hydroxyapatite, the calcium phosphate (Mucalo, 2010). In this tropical part of the world, lateritic soil are used as road making material and they form the sub grade of most tropical road, they are used as sub base and bases for low cost roads and these carry low to medium traffic. Furthermore, in rural areas of Nigeria, they are used as building material for moulding of blocks and plastering. Kaolin serves important function in the cement industry as highly calcinated; pulverized Kaolin adds comprehensive strength, flexural strength and water permeability to cement. In general 5\%-15\% activated Kaolin mixed with cement creates a superiorly strong mortar when hardened. Water permeability is useful in prolonging the durability of concretes and reduces weakening as a whole. Calcined Kaolin adds flexibility which is often preferred to the usually brittle finished product. High performance concrete (cement with Kaolin additives) can be modified to meet a variety of applications. In particular its shrinkage strength when compressed, and water permeability makes high performance concrete useful in bridge building. The aim of this study is to improve the strength of the lateritic soil collected from Olokoro in Abia State by increasing its strength and reduce its vulnerability to water and this is done by the introduction of calcined Kaolin as stabilizer and Bone Ash as an admixture at different variation in percentage. The design of earth structures require knowledge on the behaviour and stress related deformity of soil that will support the structure and geological conditions of the soil under consideration (Perloff, 1976; Okafor and Egbe, 2013; Sadeeq et al, 2015). This study tends to stabilize the problematic lateritic soil and make it fit for geotechnical projects using calcined Kaolin as stabilizing agent and bone ash as admixture. The study also shows that what we regard as waste materials can actually be of use in the engineering profession e.g. animal bone (Pety and Little, 2002).

\section{MATERIALS AND MethodS}

The materials used for this research work are lateritic soil sample obtained from a borrow site at Olokoro, Umuahia South LGA, Abia State, Nigeria that lies on latitude 05o28'36.900' 'North and longitude 07o32'23.170" East from a depth of 2.0meters (www.google.com, 2015). The sample was collected in solid state and reddish brown in colour. The soil obtained from this location was air dried in trays for six days after which the soil was crumbled. The dried soil was pulverized using a rubber covered pestle in the tray and sieve characterization with Orderly arranged British Standard Sieves to (IS: 2720-Part XVI, 1999); $4.36 \mathrm{~mm}, 2.36 \mathrm{~mm}, 1.18 \mathrm{~mm}, 600 \mu \mathrm{m}, 425 \mu \mathrm{m}, 300 \mu \mathrm{m}, 212 \mu \mathrm{m}, 150 \mu \mathrm{m}$, $75 \mu \mathrm{m}$; Lid and receiver; Balance readable and accurate to $0.1 \mathrm{~g}$, drying oven, sieve brush and the mechanical shaker was carried out on the sample and it was classified as A-2-7 soil according to AASHTO classification system (AASHTO Part II, 1982). The rubber cover was to enable the breaking up of the soil aggregates without crushing the individual particles. Distilled water was used for altering the moisture content of the sample and other test were carried out, Kaolin obtained from Agbaghara in Imo state and Bone Ash obtained from Afo-Ogbe, Mbaise in Imo State from which the phosphates content was determined by Fiske-Sub-barrow Colorimetric Method, the potassium content by Kramer's Method, the carbonate was determined in weighed amounts of Bone Ash powder in modified Van Slyke Co2 apparatus according to Kramer's procedure (Sherwood, 1993). The following tests were carried out according to (BS: 1377, 1990); Compaction Test (Standard Proctor Test), Atterberg Limit Test, Triaxial Test, California Bearing Ratio Test (CBR), Specific Gravity Test and Soil Classification/Characterization. The apparatus used for Sieve Analysis are British Standard Test Sieve; and appropriate receiver, a weighing balance and accurate to 0.01g, sample divider, a thermostatically controlled drying oven capable of maintaining a temperature of 1050c to 1100c, sieve brushes, metal trays, scoop and a mechanical sieve shaker. The Compaction Test (Standard Proctor Test) was carried out on the studied sample according to (BS 1377 Part 4, 1990) with the following apparatus; a cylindrical mould with an internal diameter of $105 \mathrm{~mm}$ and an internal effective height of $115.5 \mathrm{~mm}$, metal rammer with $50 \mathrm{~mm}$ diameter face, weight of $2.5 \mathrm{~kg}$ sliding freely in a tube which controls the height of drop to $300 \mathrm{~mm}$, jacking apparatus for extracting the compacted materials from the mould, 20mm British Standard sieves, balance readable to $5 \mathrm{~g}$, watertight container, drying oven capable of maintaining a temperature of $105^{\circ} \mathrm{C}$ to $110^{\circ} \mathrm{C}$ and a pallet knife. The Atterberg Limit Test was also carried out according to (BS 1377, 1990) with the following apparatus; Flat glass plate about $12 \mathrm{~mm}$ in diameter, spatula, Cassagrandi Liquid Limit device, grooving tool, drying oven and mass 
balance accurate to 0.01g. The Moisture Content test was carried out according to (BS 1377, 1990) with the following apparatus; Balance accurate to $0.01 \mathrm{~g}$, sample container (watch glass returns), oven $(24 \mathrm{hr}$ at $1050 \mathrm{c}+50 \mathrm{c})$ and desiccators. The Californian Bearing Ratio Test was carried out in accordance with (BS 1377, 1990) with the following apparatus; Motor driven compression machine with a constant penetration rate of $1 \mathrm{~mm} / \mathrm{min}$. The load measuring device depends on the CBR-value with a CBR value up to $30 \%$, a load ring with a range of $0-50 \mathrm{KN}$ is needed. A seating load of $250 \mathrm{~N}$ has to be applied. The displacement-measuring device had a range of $25 \mathrm{~mm}$ and scale units of $0.01 \mathrm{~mm}$, a standardized CBR mould, fittings, $20 \mathrm{~mm}$ and $37.5 \mathrm{~mm}$ British Standard sieves, balance capable of weighing up to $25 \mathrm{~kg}$ readable to $5 \mathrm{~g}$, watertight containers or strong polythene bags, a drying oven capable of maintaining a temperature of $105^{\circ} \mathrm{C}$ to $110^{\circ} \mathrm{C}$, a steel straight-edge about $300 \mathrm{~mm}$ long and $3 \mathrm{~mm}$ thick with one bevelled edge and mixer of 5 litres. The Specific Gravity Test was carried out according to (BS 1377, 1990) with the following apparatus; Pycnometer, balance, volume pump, funnel and spoon. And finally the Unconfined Triaxial Test was carried to determine strength properties; deviatoric stress, cohesion, and frictional angle of the sample under study.

\section{RESUlTS AND DISCUSSION}

From the analytical studies as shown in Table 1, the Bone Ash contains more calcium than can be accounted for on the basis of carbonate and phosphate.

Table1. Composition of Bone Ash

\begin{tabular}{|c|c|}
\hline Element/Compound Composition & Percentage \% \\
\hline $\mathrm{Ca}$ & 36.05 \\
\hline $\mathrm{Mg}$ & 0.74 \\
\hline $\mathrm{K}$ & 0.85 \\
\hline $\mathrm{P}$ & 16.43 \\
\hline $\mathrm{Co}$ & 4.58 \\
\hline
\end{tabular}

Kaolin is any of a group of fine clay minerals with the chemical composition of Al2O3.2SiO2.2H2O. Clay minerals include kaolinite, nacrite, dickite, montmorillonite, illite, chlorite, attapulgite and anauxite. Chemical compositions of kaolin minerals are same. Kaolinite is the principle constituent of kaolin. Its chemical structure is $\mathrm{Al} 2 \mathrm{Si} 2 \mathrm{O} 5(\mathrm{OH}) 4$ theoretically $39.8 \%$ aluminium $+46.3 \%$ Silica $=$ $13.9 \%$ ). Kaolinite is a hydrous aluminium silicate prepared by the chemical weathering off feldspar and decomposition of aluminium silicate rocks. It is a soft, earthy and white mineral; but is coloured light average to red by iron oxide and the above analysis is as shown in Table 2.

Table2. Composition of Bone Ash

\begin{tabular}{|c|c|c|c|c|c|c|c|c|c|c|c|c|}
\hline Compound & $\mathrm{Al}_{2} \mathrm{O}_{3}$ & $\mathrm{Si}_{2} \mathrm{O}_{2}$ & $\mathrm{Fe}_{2} \mathrm{O}_{3}$ & $\mathrm{Ti}_{2} \mathrm{O}_{2}$ & $\mathrm{MnO}$ & $\mathrm{P}_{2} \mathrm{O}_{5}$ & $\mathrm{Na}_{2} \mathrm{O}$ & $\mathrm{CaO}$ & $\mathrm{MgO}$ & $\mathrm{K}_{2} \mathrm{O}$ & $\mathrm{SO}_{3}$ & $\mathrm{Ph}$ value \\
\hline Percentage \% & 39.0 & 43.5 & 0.70 & 0.60 & 0.30 & 0.30 & 0.20 & 0.30 & 0.30 & 0.20 & 0.03 & $6-8$ \\
\hline
\end{tabular}

The result of the soil classification and characterization test is as shown in Fig. 1.

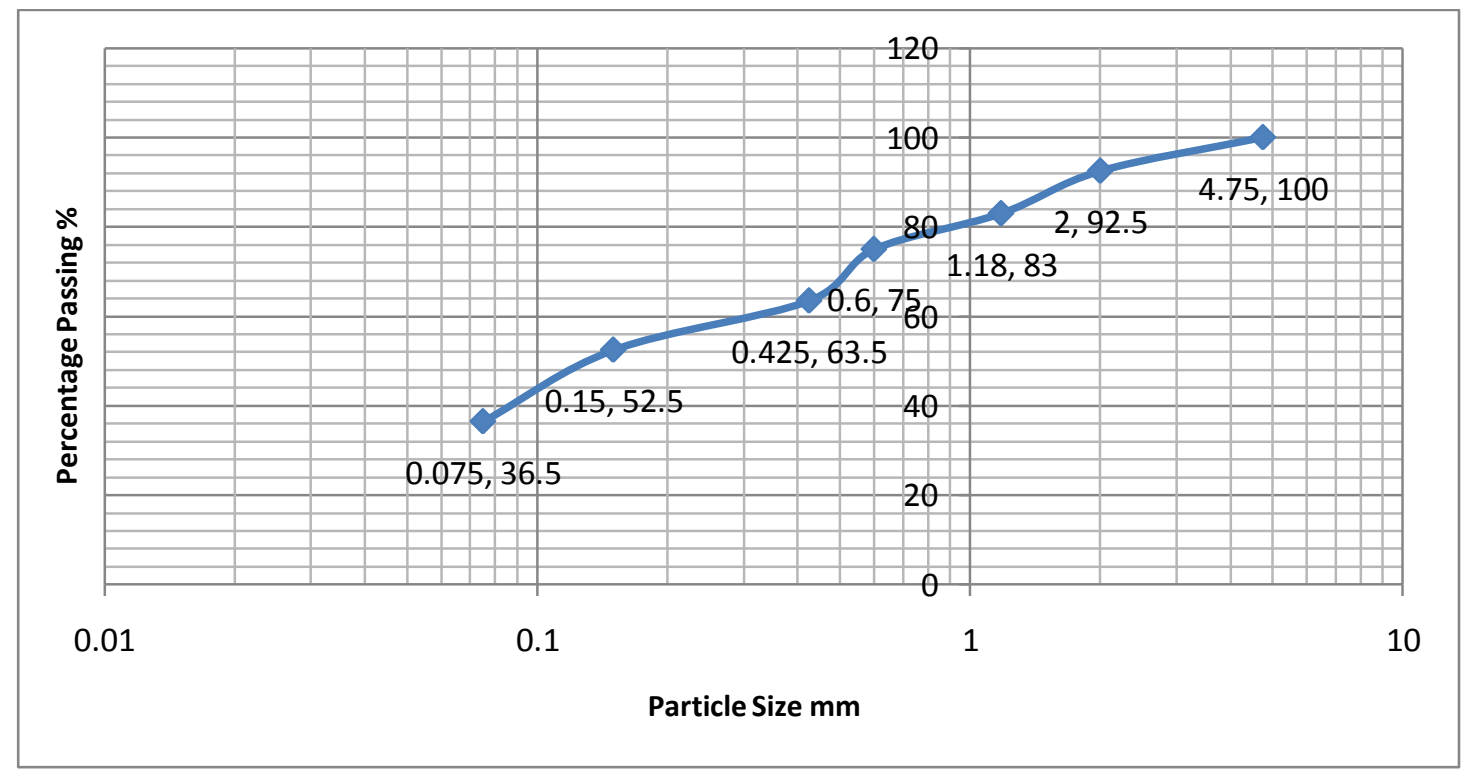

Fig1. Soil sieve analysis chart 


\section{Onyelowe, K. C}

The sample was classified according to AASHTO soil classification system as A7-5 (6) based on its Liquid Limit, Plastic Index and percentage passing No $200(75 \mu \mathrm{m}) \mathrm{BS}$ sieve. The soil type is clayey soil with Plastic Limit of 26.9 and Liquid Limit of 60.0 and Plasticity Index of 33.1. It is observed that the Plasticity Index falls between 30 and $70 \%$ as shown in Fig.2 which shows that the soil is highly plastic (White, 2000).

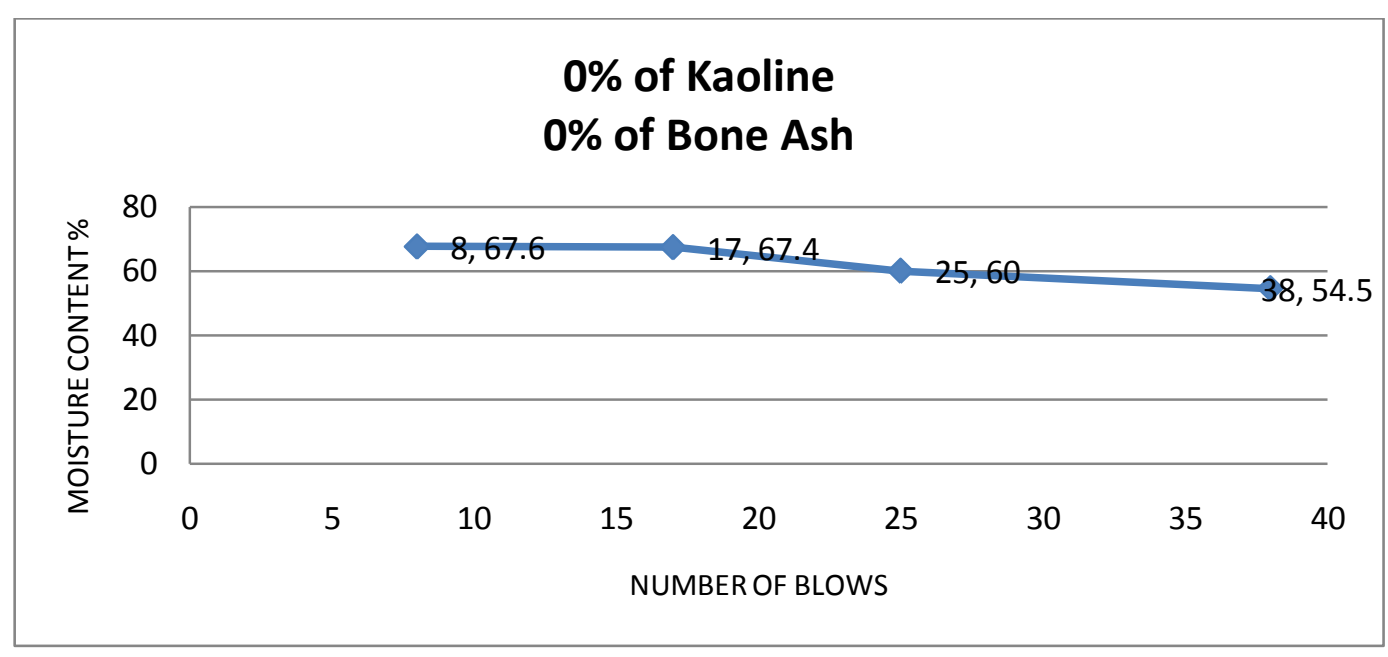

Fig2. Atterberg Limit result at $0 \%$ BA and Kaolin

Furthermore, Figures 3, 4, 5, 6, 7 shows the effect of varied proportion of BA at 10\% Kaolin on the plastic limit, liquid limit and plasticity index of the soil sample.

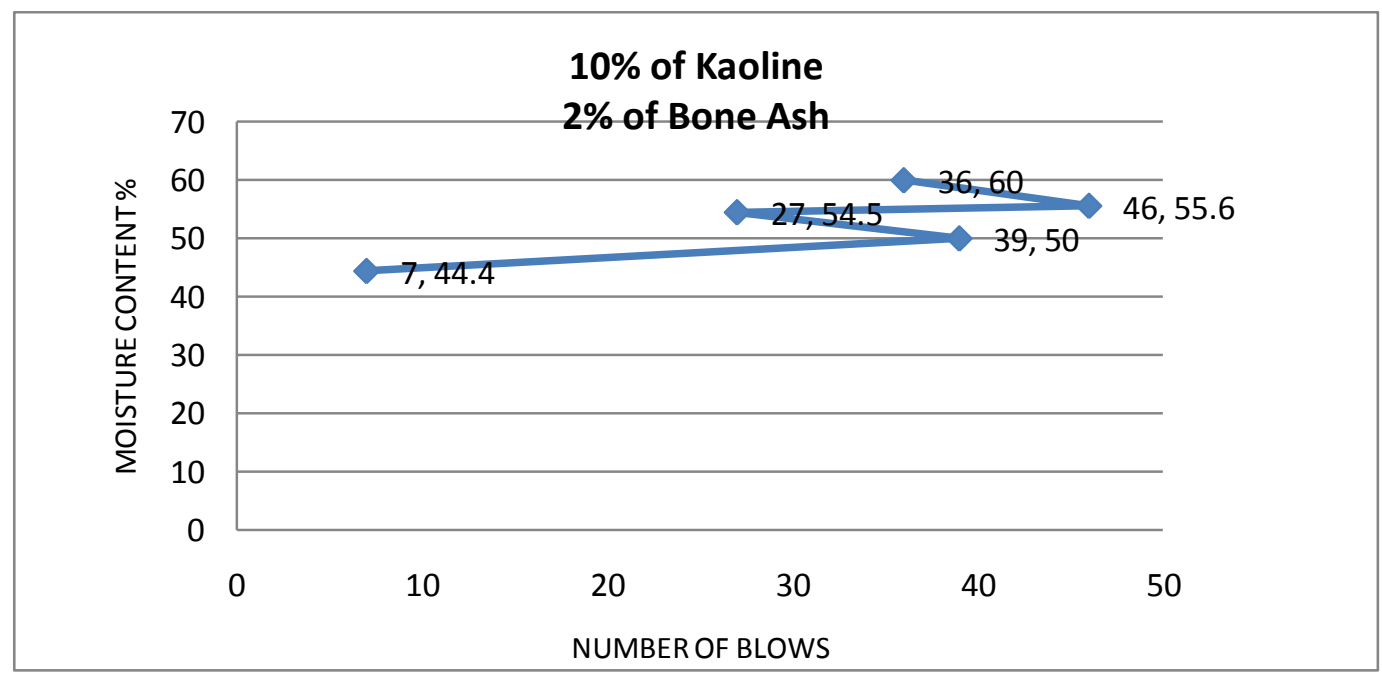

Fig3. Atterberg limit test graph (10\% Kaolin, 2\%Bone Ash)

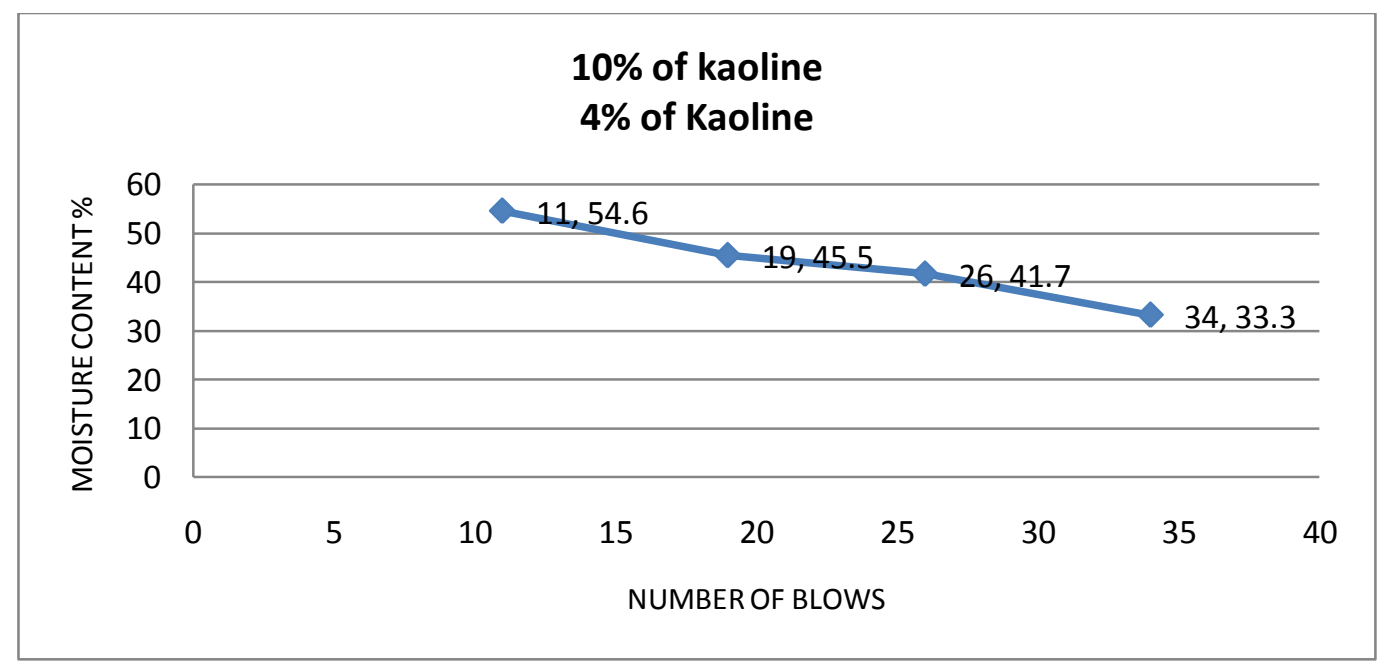

Fig4. Atterberg limit test graph (10\% Kaolin, 4\%Bone Ash) 


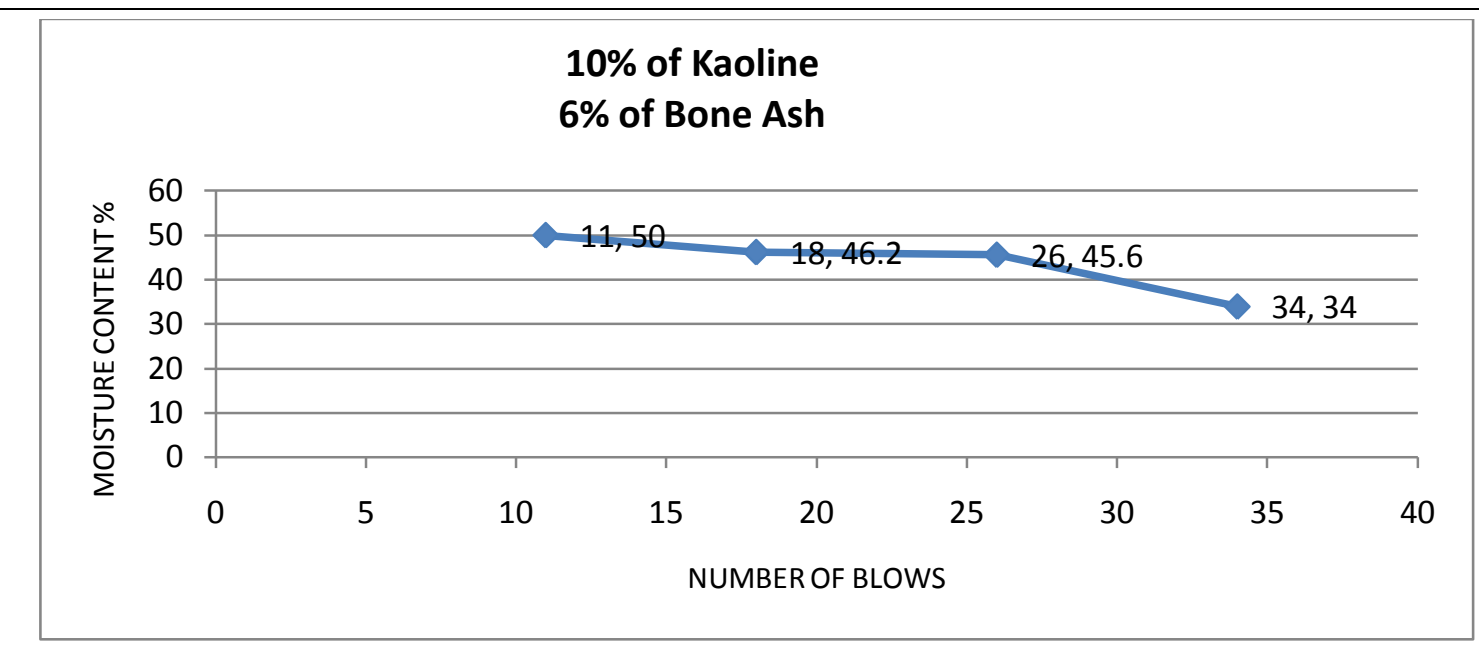

Fig5. Atterberg limit test graph (10\% Kaolin, 6\%Bone Ash)

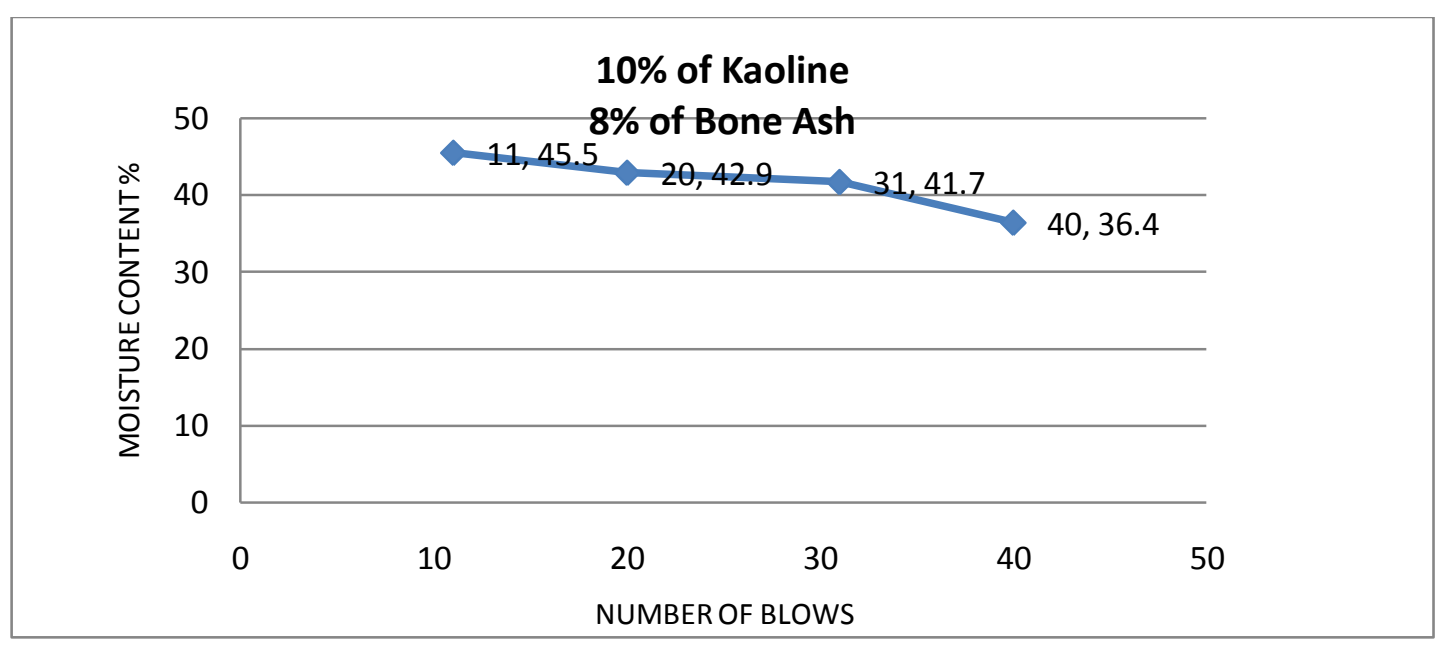

Fig6. Atterberg limit test graph (10\% Kaolin, 8\%Bone Ash)

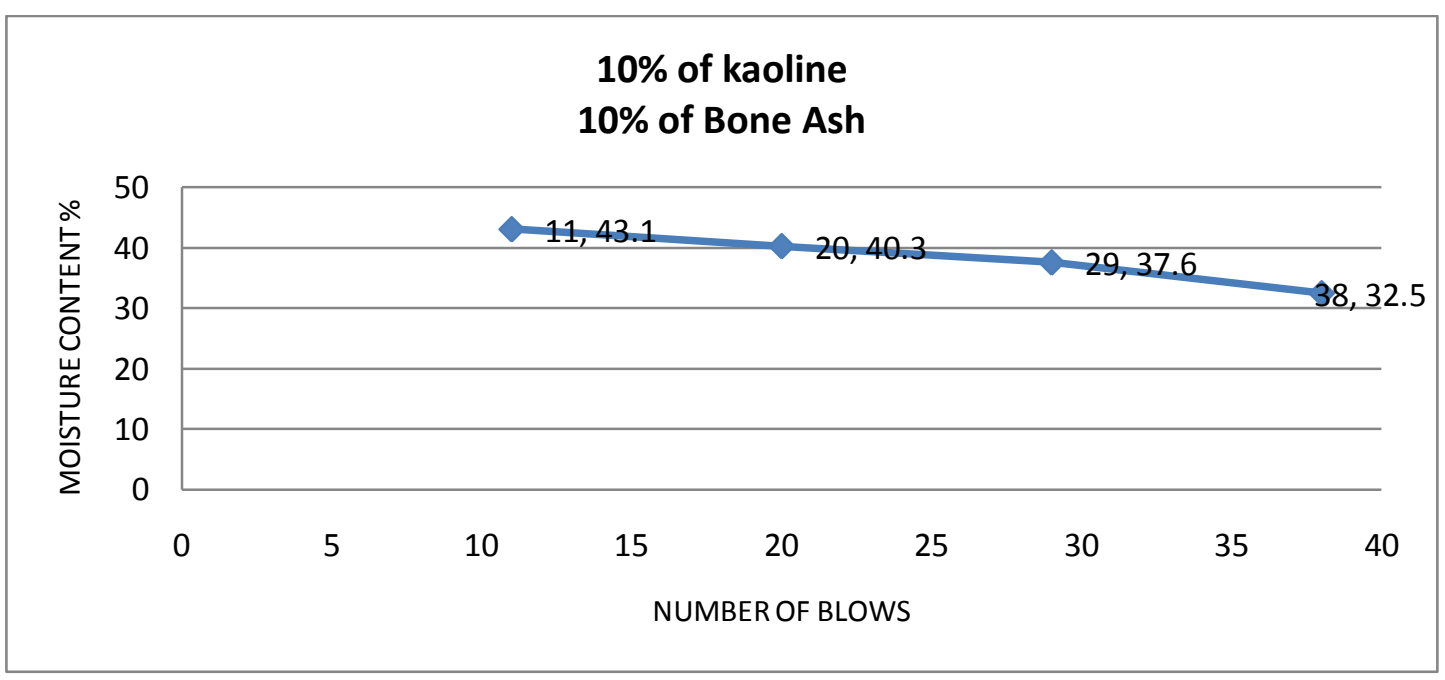

Fig7. Atterberg limit test graph (10\% Kaolin, 10\%Bone Ash)

Table3. Effect of Kaolin and BA on the Atterberg Limit test of studied sample

\begin{tabular}{|c|c|c|c|c|c|c|}
\hline BA (\%) & 0 & 2 & 4 & 6 & 8 & 10 \\
\hline LL (\%) & 60.00 & 48.00 & 42.00 & 45.20 & 44.10 & 38.50 \\
\hline PL (\%) & 26.90 & 28.50 & 26.00 & 25.40 & 25.00 & 23.95 \\
\hline PI (\%) & 33.10 & 19.50 & 16.00 & 19.80 & 19.10 & 14.55 \\
\hline
\end{tabular}

It will be discovered that the Liquid Limit, Plastic Limit and Plastic Index decreased with reference to the control test as the admixture increased as shown in Figures 2, 3, 4, 5, 6 and 7 and Table 3 with the introduction of greater percentage of bone ash. This behaviour was due to the increase in the thickness 


\section{Onyelowe, K. C}

of the diffused double layer as the admixture content increased (Pousette et al, 1999). The relationship between dry density and moisture content for different percentage of admixture, BA and stabilizer, Kaolin on the soil sample at different moisture percentages are as shown in Figures 8, 9. 10, 11, 12, 13 and Table 4

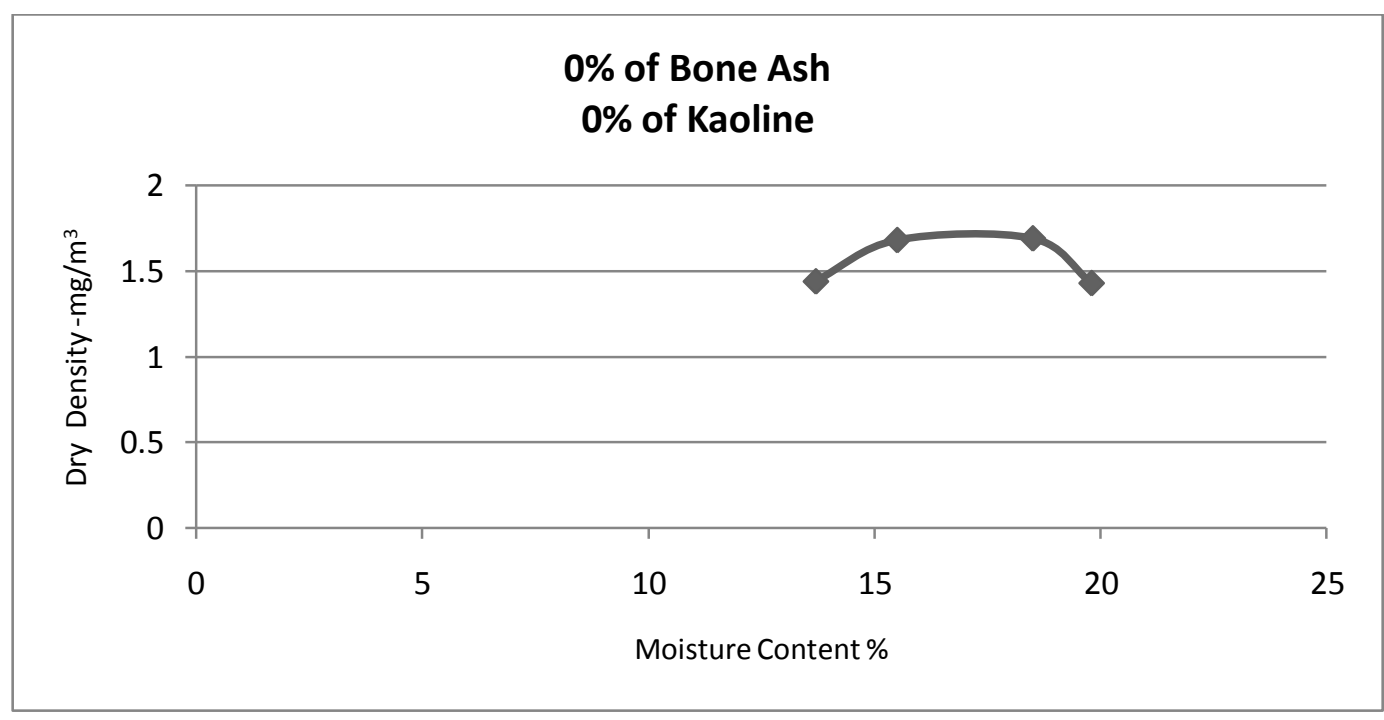

Fig8. Compaction at $0 \%$ Kaolin and $0 \%$ Bone Ash

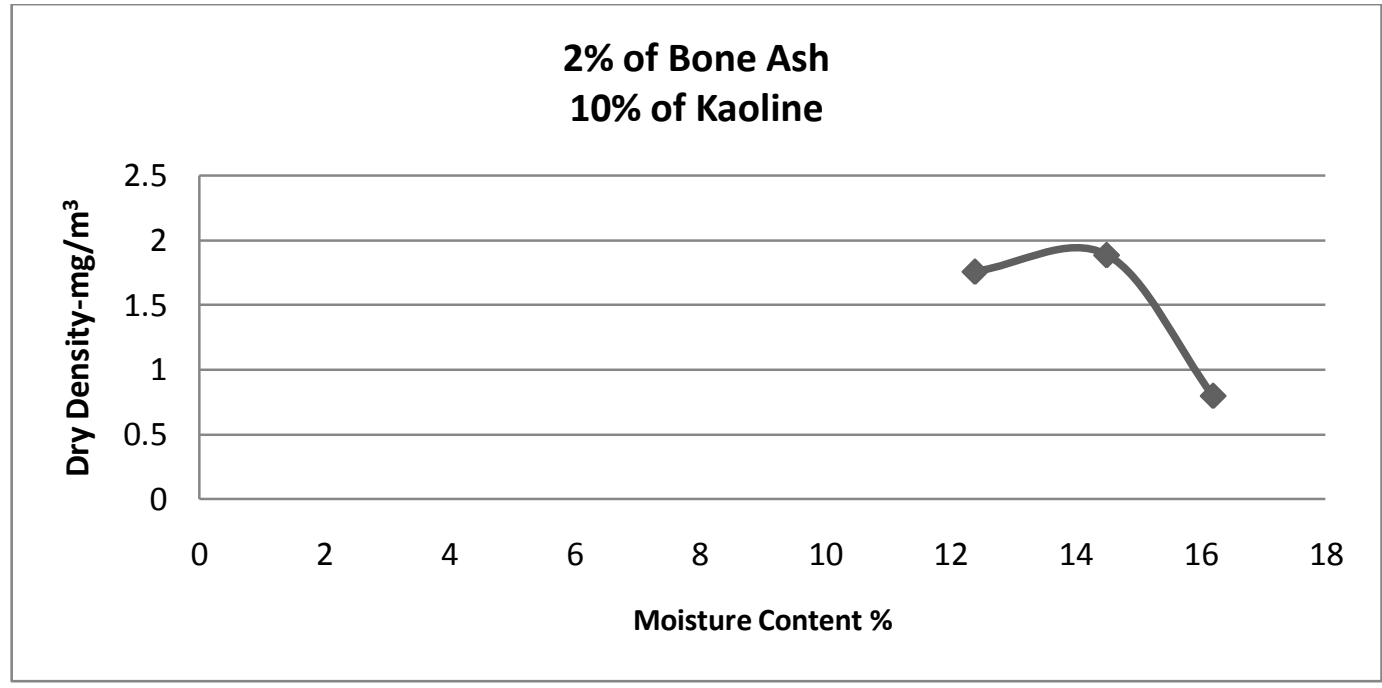

Fig9. Compaction at $10 \%$ Kaolin and $2 \%$ Bone Ash

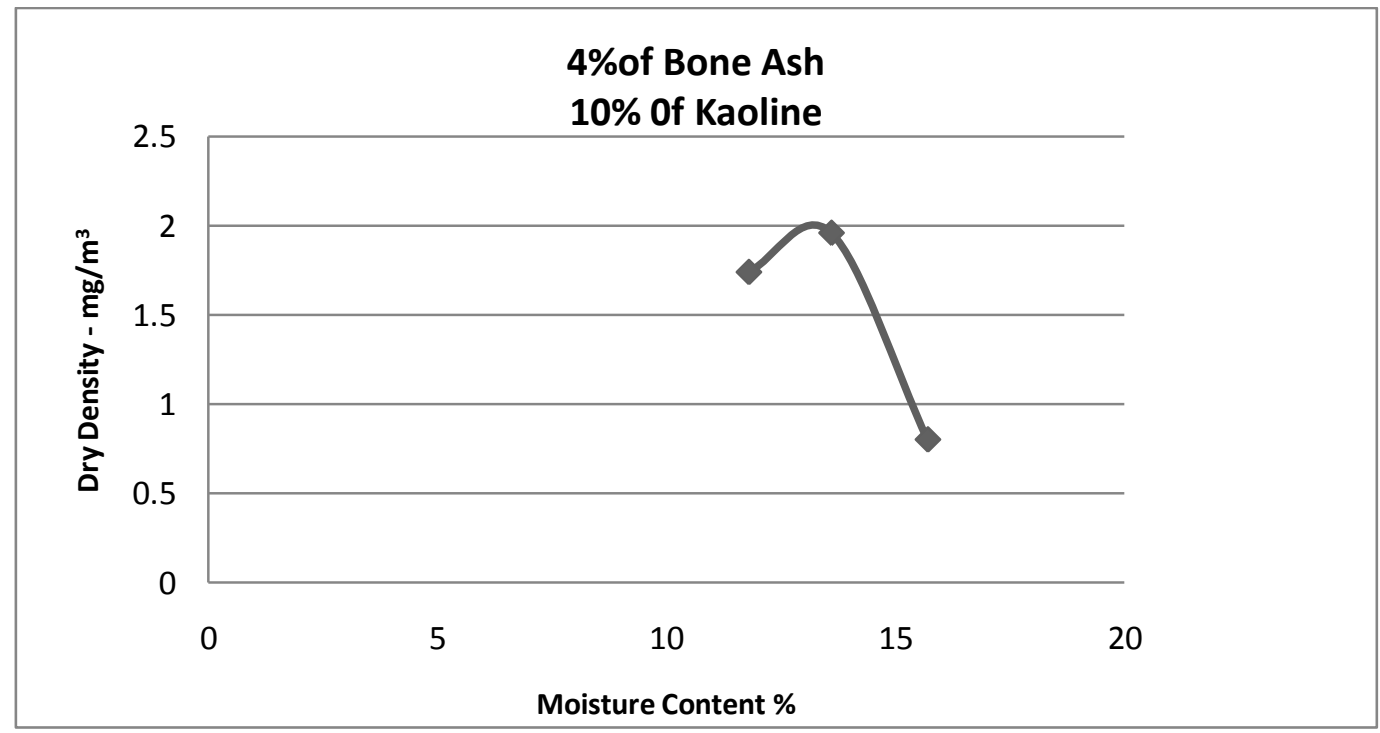

Fig10. Compaction at $10 \%$ Kaolin and $4 \%$ Bone Ash 


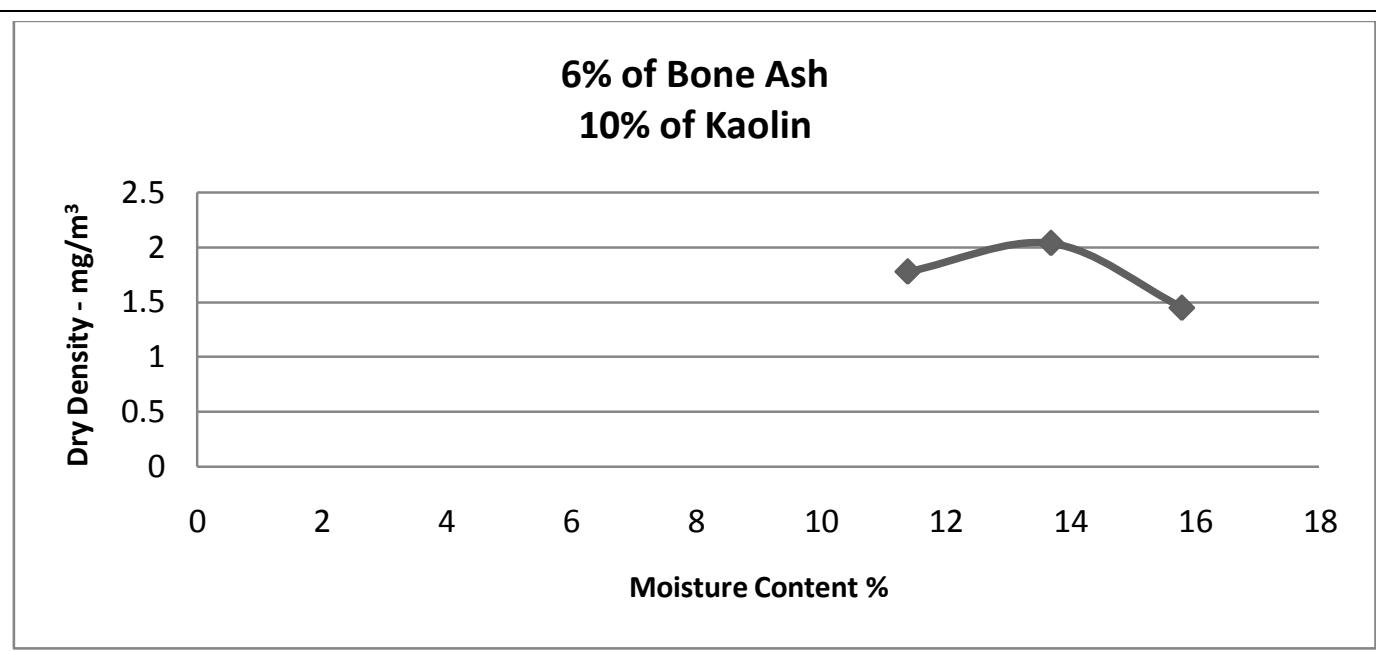

Fig11. Compaction at $10 \%$ Kaolin and $6 \%$ Bone Ash

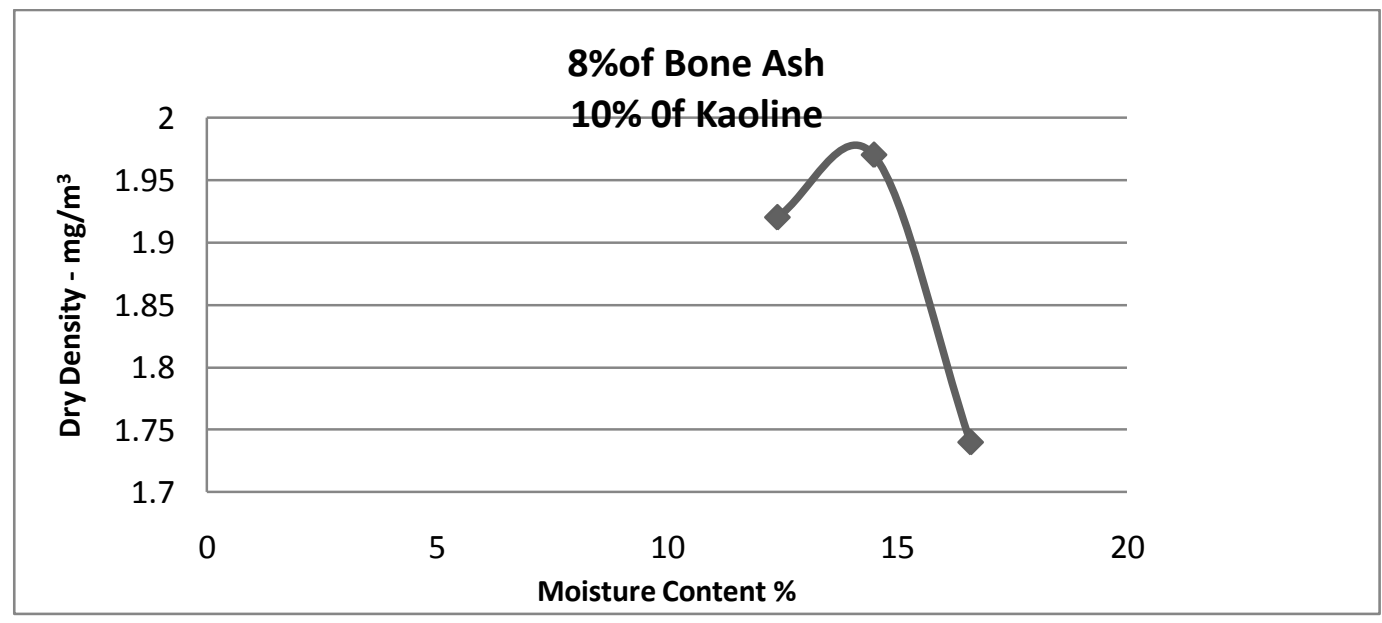

Fig12. Compaction at $10 \%$ Kaolin and $8 \%$ Bone Ash

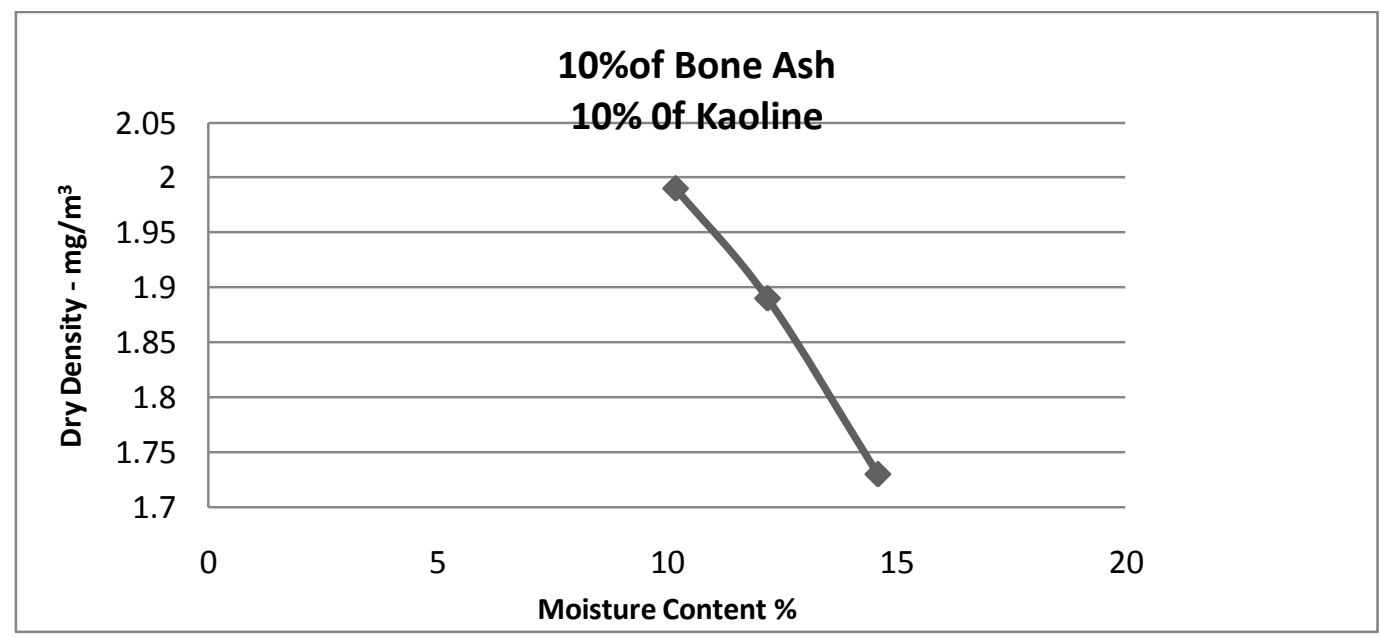

Fig13. Compaction at $10 \%$ Kaolin and 10\% Bone Ash

Table4. Effect of Kaolin and BA on the MDD and OMC of studied sample

\begin{tabular}{|c|c|c|c|c|c|c|}
\hline BA (\%) & 0 & 2 & 4 & 6 & 8 & 10 \\
\hline MDD $\left(\mathrm{mg} / \mathrm{m}^{3}\right)$ & 1.66 & 1.93 & 2.20 & 2.30 & 1.98 & 1.99 \\
\hline OMC $(\%)$ & 17.00 & 14.00 & 13.10 & 13.50 & 14.20 & 10.10 \\
\hline
\end{tabular}

From Table 4, it has been observed that the MDD increased considerably from $1.66 \mathrm{mg} / \mathrm{m} 3$ at $0 \%$ BA to $2.30 \mathrm{mg} / \mathrm{m} 3$ at $6 \%$ BA which is a good density and dropped to $1.98 \mathrm{mg} / \mathrm{m} 3$ and $1.99 \mathrm{mg} / \mathrm{m} 3$ at $8 \%$ and $10 \%$ BA respectively. On the hand, the OMC decreased along the same line and achieved $13.50 \%$ at the best MDD of $2.30 \mathrm{mg} / \mathrm{m} 3$ at $6 \%$ BA. 
The CBR test was carried and results as shown in Table 5 has shown that at $10 \%$ Kaolin content, addition of Bone Ash up to $8 \%$ increased the CBR to $80.3 \%$, and further increase in Bone Ash decreased CBR to $57.1 \%$, indicating that at $10 \%$ of Kaolin and $8 \%$ of Bone Ash the acceptable value for CBR was reached;

Table5. Effect of $10 \%$ Kaolin and BA on the CBR of sample on volume of mould $=2351 \mathrm{~cm} 3$

\begin{tabular}{|c|c|c|c|c|c|c|}
\hline BA (\%) & 0 & 2 & 4 & 6 & 8 & 10 \\
\hline CBR (\%) & 29.7 & 38.3 & 49.9 & 60.8 & 80.3 & 57.1 \\
\hline
\end{tabular}

This value is acceptable for base course materials according to general specifications for road, foundation and bridges by federal ministry of works lands, and transport (FMWHT, 1997).

And finally, the Triaxial test was conducted on the studied sample and the results are as shown in Table 6.

Table6. Triaxial test result on the studied sample

\begin{tabular}{|c|c|c|c|c|c|c|}
\hline $\mathrm{BA}(\%)$ & 0 & 2 & 4 & 6 & 8 & 10 \\
\hline $\mathrm{Cu}\left(\mathrm{KN} / \mathrm{m}^{2}\right)$ & 26 & 21 & 18 & 44 & 22 & 38 \\
\hline$\Theta\left({ }^{\circ}\right)$ & 17 & 19 & 19 & 17 & 29 & 19 \\
\hline
\end{tabular}

Results in Table 6 above have shown the effect of various percentages of BA on the soil sample stabilized with Kaolin. The highest cohesion of $44 \mathrm{KN} / \mathrm{m} 2$ was achieved at $6 \%$ BA and frictional angle of $29^{\circ}$.

\section{CONCLUSION}

From the research work, it can be concluded that; MDD, OMC, Cohesion and CBR properties improved by the addition of BA as admixture to the soil sample Kaolin stabilization. It was found out that at $16 \%$ of moisture content, $10 \%$ Kaolin and $8 \%$ Bone Ash, the CBR value of the stabilized soil sample increased considerably to $80.3 \%$ which makes it suitable for any construction work including its use as sub-base material for pavement construction. The present research findings have implored constructors to make use of available waste materials like the studied BA to improve the geotechnical engineering properties of weak engineering soils before use as foundation soils in pavement constructions and in backfills.

\section{REFERENCES}

[1] American Association of State Highway and Transportation Officials (AASHTO), Standard specification for transportation materials and methods of sampling and testing, 1982, Part II.

[2] Ayininuola, G. M and Agbede, A. O (2009), Influence of bone ash in soil California Bearing Ratio (CBR), Journal of Emerging Trends in Engineering and Applied Sciences (JETEAS) Vol.5 No.8 Pp.235-237.

[3] Behzad, K and Huat, B.B.K (2008), Peat Soil Stabilization using Ordinary Portland Cement, Polypropylene Fibres, and Air-Curing Technique, EJGE, USA, Vol. 13, Pp. 1.

[4] BS 1377 (1990), Methods of test for soils for civil engineering purposes, UK British Standard Institute, Chapter 21, McGraw Hill Company Inc., New York, USA.

[5] Federal Ministry of Works and Housing (1997), General Specifications for Roads and Bridges, Federal Highway Department: Lagos, Nigeria. Volume II.145-284

[6] IS: 2720-Part XVI (1999), Laboratory CBR Apparatus.

[7] Mucalo M. (2010), Processing cow bone for human use, proceeding of the International Conference on Deep Mixing-Best Practice and Recent Advances, Stockholm.

[8] Okafor, F.O. and Egbe, E.A. (2013), Potentials of cement kiln dust (CKD) in sub grade improvement, NIJOTECH, Vol. 32, No. 1, Pp. 109-116.

[9] Perloff , W.H.(1976) . Soil Mechanics, Principles and Applications, John Wiley and Sons, New York

[10] Pety,T.M and Little, D.N.(2002), Review of stabilization of clays and expansive soils in pavement and lightly loaded structures-history, practice and future;ASC Journal of materials in Civil engineering, 2002,vol.14, no 6. Pp 447-460. 
[11] Pousette, K., Mácsik, J. and Jacobsson, A. (1999), Peat Soil Samples Stabilized in LaboratoryExperiences from Manufacturing and Testing, Proceeding of Dry Mix Methods for Deep Stabilization (pp. 85-92), Rotterdam.

[12] Sadeeq, J.A., Ochepo, J. and Salahudeen, A.B. (2015), Assessment of bagasse ash effect on the California bearing ratio of used oil contaminated lateritic soils, NIJOTECH, Vol. 34, No. 2, Pp. 223-231.

[13] Salahudeen, A.B. and Akiije, I. (2014), Stabilization of highway expansive soils with high loss of ignition content kiln dust, NIJOTECH, Vol. 33, No. 2, Pp. 141-148.

[14] Sherwood, P. (1993), Soil stabilization with cement and lime, State of the Art Review, London: Transport Research Laboratory, HMSO.

[15] White, D. (2000), Fly Ash Soil Stabilization for Non-Uniform Subgrade Soils, IHRB Project TR461, FHWA Project 4.35

[16] www.Google.com (2015), Latitude and Longitude of Olokoro, Umuahia, accessed on October 25,2015

\section{AUTHOR's BIOGRAPHY}

Onyelowe Kennedy Chibuzor, $\mathrm{PhD}$ born December 25, 1978 is a lecturer and researcher in the field of Geotechnical Engineering with the Michael Okpara University of Agriculture, Umudike, Umuahia, Nigeria. He holds a bachelors degree in Civil Engineering from the Federal University of Technology, Owerri, Nigeria and Masters and Doctor of Philosophy degrees in Geotechnical Engineering from the University of Nigeria, Nsukka. He has several publications to his credit. He enjoys THINKING and meditating on the UNITY in all CREATION. 